\section{ECONOMICS}

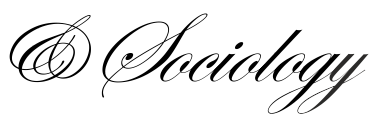

Sumiyana Sumiyana, University of Gadjah Mada, Yogyakarta, Indonesia,

E-mail:sumiyana@ugm.ac.id ORCID 0000-0002-1518-9681

Sari Atmini, Doctorate Student at University of Gadjah Mada, Yogyakarta, Indonesia,

E-mail:sariatmini@ub.ac.id

\author{
Slamet Sugiri, \\ University of Gadjah Mada, \\ Yogyakarta, Indonesia, \\ E-mail:slamet.sugiri@ugm.ac.id \\ Received: August, 2018 \\ 1st Revision: November, 2018 \\ Accepted: February, 2019
}

DOI: $10.14254 / 2071-$

789X.2019/12-1/7
Sumiyana, S., Atmini, S., \& Sugiri, S. (2019). Predictive power of aggregate corporate earnings and their components for future GDP growths: An international comparison. Economics and Sociology, 12(1), 125-142. doi:10.14254/2071-789X.2019/12-1/7

\title{
PREDICTIVE POWER OF AGGREGATE CORPORATE EARNINGS AND THEIR COMPONENTS FOR FUTURE GDP GROWTHS: AN INTERNATIONAL COMPARISON
}

\begin{abstract}
This study investigates the predictive power of aggregate corporate earnings and their four components for future GDP growths. It splits aggregate earnings into operating and non-operating incomes as they have different degrees of permanence. It also splits aggregate earnings into operating cash flows and accruals since earnings management affects them distinctively. This study finds aggregate earnings, operating income, operating cash flows, and accruals as predictors for oneand two-years-ahead GDP growths. However, it does not find such predictive power for aggregate non-operating income. Furthermore, this study splits the research sample based on macroeconomic development level and documents how aggregate earnings have predictive power over the longer horizon in developed countries, while aggregate non-operating income is a good predictor only in developing countries. Meanwhile, when splitting the sample based on earnings quality degree, this study demonstrates that the predictive power of aggregate accruals in a high earnings quality subsample is higher than in the low one. In the context of high (low) earnings quality, the predictive power of aggregate accruals is higher (lower) than that of operating cash flows. Overall, besides supporting previous studies' findings, this study also discovers that corporate earnings components are excellent predictors for future GDP growths.
\end{abstract}

Keywords: aggregate earnings, earnings components, future GDP growths, international settings.

\section{Introduction}

This study investigates whether aggregate corporate earnings and their components have predictive content for future gross domestic product (GDP) growths. Konchitchki and Patatoukas (2014a) and Konchitchki and Patatoukas (2014b) provide evidence that aggregate corporate earnings have such predictive power. Their research findings indicate that aggregate accounting earnings growth can predict future nominal GDP growths, especially for the one- 
quarter-ahead forecast horizon (Konchitchki \& Patatoukas, 2014a), as well as subsequent real GDP growths (Konchitchki \& Patatoukas, 2014b).

Earnings informativeness studies at the macroeconomy level take the position of "micro to macro" by investigating the association between accounting and macroeconomic data (Konchitchki \& Patatoukas, 2014a). The underlying argument is that corporations account for a significant segment in the macroeconomy and that their activities in aggregate affect macroeconomy (Kothari, Shivakumar, \& Urcan, 2013). However, studies that associate aggregate corporate earnings and macroeconomic activities are still rare (Shivakumar, 2007). Such studies are essential since empirical findings at the firm level may not be useful yet to infer the earnings' informativeness at the macroeconomy level (Anilowski, Feng, \& Skinner, 2007).

This study offers novelty because it differs from previous research for two critical reasons. First, this study investigates both the predictive power of aggregate corporate earnings for future GDP growths and their components. Previous studies (Konchitchki \& Patatoukas, 2014a, 2014b) have not taken into account the information content of aggregate earnings components at the macroeconomy level, whereas each type offers different value relevances. Lipe (1986) suggested that earnings disaggregation provides incremental explanatory power. Moreover, Fairfield, Sweeney, and Yohn (1996) and Richardson, Sloan, Soliman, and Tuna (2005) also suggest that earnings disaggregation is more useful for predicting future earnings. This study decomposes aggregate corporate earnings into aggregate operating income, nonoperating income, operating cash flows, and accruals. This study uses aggregate operating and non-operating incomes since they usually have different degrees of permanence. In the meantime, this study also uses aggregate operating cash flows and accruals because earnings management affects them distinctively (Wang, Cao, Li, \& Liu, 2015).

Second, this study conducts its investigation in the international settings. Its sample consists of 44 countries which allows performing two additional analyses to explore the effect of two country-specific factors. The two country-specific factors considered for further investigation are the level of macroeconomic development and the degree of earnings' quality. This study divides the research sample based on its macroeconomic development level into developed and developing countries. These two groups of countries have different characteristics, such as the level of the underground economy (Schneider, 2005) and economic uncertainty. Different characteristics may affect the predictive power in the association between aggregate corporate earnings and future GDP growths. Meanwhile, this study posits Wang et al. (2015), suggesting that the existence of earnings management will weaken the predictive power of the association between accounting earnings and future GDP growths. Earnings management is one proxy of earnings quality (Dechow, Ge, \& Schrand, 2010). Therefore, this study expects the degree of earnings quality to influence the predictive power of the association between accounting earnings and future GDP growths. This research splits the sample into high and low earnings qualities proxied with earnings persistence (Dechow et al., 2010) to investigate the influence.

This study collects 264 observations from 44 countries during the period of 2010-2016. From the primary analysis, this study finds that aggregate corporate earnings, as well as aggregate operating income, operating cash flows, and accruals can predict future GDP growths for one and two years ahead. However, this study does not find any evidence for the predictive power of aggregate non-operating income for future GDP growths.

From the additional analysis, the results show different findings between developed and developing countries. In developed countries, aggregate corporate earnings, operating cash flows and accruals can predict future GDP growths for one and two years ahead. Meanwhile, the aggregate operating income can only predict one-year-ahead GDP growth. In contrast, 
aggregate non-operating income does not have such predictive power. This study finds that aggregate non-operating income, operating cash flows, and accruals have predictive power for one- and two-years-ahead GDP growths in the developing countries. However, aggregate corporate earnings and operating income can only predict one-year-ahead GDP growth. Moreover, the study's results find differences in high and low earnings' qualities. The predictive power of aggregate accruals in high earnings quality is higher than that in the low earnings' quality subsample. In the high earnings' quality subsample, the predictive power of aggregate accruals goes beyond that of the operating cash flows. By contrast, in a low earnings' quality subsample, the predictive power of aggregate operating cash flows is higher than that of accruals.

This study contributes to the research's line of "micro to macro." It means that this study refers to all previous literature related to the issue of macroeconomic forecasting research based on accounting (micro) data. This study's dominant contributions are the usefulness of aggregate earnings' components and its international settings. This study collects a sample consisting of many countries with a nation-year unit of analysis. Because of its international data sample, this research then compares the predictive power of aggregate corporate earnings and their components between developed and developing countries. Furthermore, this study compares the predictive power of aggregate corporate earnings and its components between high and low earnings' qualities.

This paper is organised as follows. The next section elaborates on the literature review and hypotheses development. Section three explains the research method and comprises data, hypotheses testing, and additional tests for robustness. Section four describes the hypotheses' test results, additional analysis results, and discussion. Section five presents conclusions, limitations, and suggestions for future research.

\section{Literature review}

\subsection{Accounting earnings and the macroeconomy}

McCloskey (1993) argues that accounting data can explain many macroeconomic phenomena. The linkage between accounting numbers and macroeconomic phenomena, among others, appears in the market index or economy-wide index models (Gonedes, 1973). The market index model represents an attempt to use the implications of market phenomena to explain the company's operating performance. That model describes a company's accounting numbers such as income levels and rates of stockholders' return by capitalising the effect of cross-sectional dependencies. The effects then influence the company's operations at immediate and future periods. The occurrence of cross-sectional dependency is partly due to macroeconomic events that immediately affect a company's entire operations. It undertakes the input-output market transactions. At the same time, a company's' operation cannot avoid conducting the transactions. For example, the potential sources of cross-sectional dependencies are the technologies of machinery that could change the whole economy, the effect of economic stabilisation policies, as well as the resources flow and relative price changes associated with the power of general equilibrium (Gonedes, 1973).

Harvey (1989) suggests that the aggregate earnings of companies associate positively with economic growth. It means that this suggestion underlies the association between accounting earnings and the macroeconomy. It also suggests that stock prices contain real firms' activity information. Ball, Sadka, and Sadka (2009) also state that there are systematic components in firms' earnings variations that affect their stock prices in the capital market. Furthermore, earnings and returns factors associate with industrial production change, real GDP 
growths, unemployment rate, and national inflation. In other words, firm-level accounting earnings have information content influencing investors' behaviours in the capital market. The aggregate accounting earnings probably contain information contents that are useful to predict macroeconomic performances. Harvey (1989) and Ball et al. (2009) align with Patatoukas (2014) that there are associations between accounting earnings, aggregate capital market level and their relevances for macroeconomic valuation. This is that there is a real association between accounting earnings and the macroeconomy.

Some previous research has investigated the relationship between accounting numbers, especially earnings and macroeconomic activities. Harvey (1989) finds evidence that stock and bond market data contain value relevances to predict gross national product. Meanwhile, Kothari, Lewellen, and Warner (2006) demonstrate that companies' earnings and their debt discount rates move together identically. Ball et al. (2009) document the relationship between a firm's earnings and their share returns with the industry's production change, real GDP growth, inflation, and unemployment rates. Prior research also links aggregate earnings and inflation. Research findings provide empirical evidence that aggregate earnings changes can predict and associate positively (Shivakumar, 2007) as well as contain value relevance with future inflation (Kothari et al., 2013).

\subsection{Aggregate accounting earnings and the future GDP growths}

Creative destruction theory (Schumpeter, 2003) argues that economic development occurs when companies implement new products, production processes, and organisational techniques or entrepreneurship. Resources should be reallocated from low-productive to highproductive companies. The resources reallocation is probably more significant during periods of high productivity dispersion than periods of low dispersion. However, it would mean friction deceleration for the resources allocation and produce the misallocation, and so temporarily resulting in a low output rate (Foster, Haltiwanger, \& Krizan, 2006; Foster, Haltiwanger, \& Krizan, 2001; Schumpeter, 2003). Moreover, according to sectoral shifts theory (Lilien, 1982), higher performance dispersion will cause labour migration from worse-performing to betterperforming companies. Friction, in the form of expenditures for the acquisition of new skills and jobs, causes a delay in labour transfers. As a result, the unemployment rate will be higher while consumption and aggregate output will be lower (Lilien, 1982; Lucas \& Prescott, 1974). Both creative destruction and sectoral shift theories suggest that productivity at the firm-level (micro level) will influence the dynamics of aggregate productivity growth at the macro level. It implies that firm-level accounting earnings, a number that represents a company's productivity, influence whole income numbers at the macroeconomy level reflected in the GDP.

Previous research provides empirical support for the relationship between accounting earnings and the future GDP growths (Konchitchki \& Patatoukas, 2014a, 2014b). It implies that aggregate accounting earnings growth is the primary indicator of the incremental value of the nominal and real GDP growths. This study posits what Konchitchki and Patatoukas (2014a) and Konchitchki and Patatoukas (2014b) argued that accounting earnings used to determine the future GDP growths. This study argues that GDP is a reflection of the whole income generated by all firms and households in a particular country. Accounting earnings are numbers that reflect firms' net income. Meanwhile, firms listed on a country's stock exchange represent a substantial portion of the country's macroeconomy. Moreover, this study argues that because of aggregate accounting earnings are a part of the entirety of national economic activities. It means that the aggregate supports the determination of the GDP's movements. Therefore, this study uses the aggregate firms' earnings to construct a hypothesis as follows:

$\mathbf{H}_{1}$ : Aggregate accounting earnings affect the future GDP growths positively. 


\subsection{Aggregate earnings components and the future GDP growths}

Firms' earnings components are incrementally informative for predicting future earnings. There is a tendency for earnings components to play an increasingly important role when they are used to predict future earnings. Investors also tend to use earnings components when they desire a higher degree of precision in predicting their stock gains (Bratten, 2009). The precisely predictive degrees are due to different profit components having dissimilar values (Fairfield et al., 1996; Finger, 1994; Sloan, 1996). This means that the earnings disaggregation will improve the predictions of future earnings performance (Barth, Cram, \& Nelson, 2001; Fairfield et al., 1996).

Previous research has investigated the predictive power of earnings components. The research findings demonstrate that earnings disaggregated into their components provide additional information (Lipe, 1986). The disaggregation also increases the ability to predict future earnings and cash flows (Barth, Beaver, Hand, \& Landsman, 1999; Fairfield et al., 1996). Besides, the disaggregation offers a different magnitude of stocks' returns reaction (Barth, Beaver, \& Wolfson, 1990; Bowen, 1981; Gonedes, 1975; Lipe, 1986). In other words, earnings disaggregation increases its predictive power at the firm level (future earnings and cash flows) as well as at the market level (stocks' returns). Based on these findings, this study expects that earnings disaggregation has predictive power that could measure the macroeconomy level, especially the future GDP growths.

This study disaggregates earnings into operating and non-operating incomes. Both components represent recurring and non-recurring items. Operating income is the result of the firm's main operating activities, while non-operating income is derived from other main activities related to the firms' primary operations. Different firms' transactions and events underlying operating and non-operating incomes resulted in their predictive power being distinctive (Fairfield et al., 1996). Besides, the permanence level of operating income is higher than non-operating income. Based on stochastic processes, differences in the permanence level of earnings components leads to their predictive power (Griffin, 1977). The more permanent the earnings components are, the stronger the predictive power is.

This study believes the logical reasoning that the predictive power of operating income is different from that of non-operating one, as well. However, both kinds of income could determine future GDP growth. This study argues that the aggregate firms' operating income, as a part of accounting earnings, could explain GDP growths more clearly (more elegantly) than the total aggregate accounting earnings themselves. This is because of more real economic productivities being conducted by all firms in a nation than the aggregate earnings having accrual and deferral manipulations. Meanwhile, the aggregate firms' non-operating income also has the same reflection as the operating one. This study, then, investigates the predictive ability of both operating and non-operating income to forecast the future GDP growths. Therefore, this study formulates the hypotheses as follows:

\section{$\mathbf{H}_{2}$ : Aggregate operating income affects the future GDP growths positively. \\ $\mathbf{H}_{3}$ : Aggregate non-operating income affects the future GDP growths positively.}

This study also disaggregates earnings into operating cash flows and accruals, consistent with the accounting literature stating that earnings consist of the two components (P. M. Dechow \& Dichev, 2002). Operating cash flows reflect the net cash flows generated by operating activities and are closely related to the company's marketing and sale policies. Therefore, it is more difficult for managers to manipulate such components (Wang et al., 2015). Conversely, managers estimate accruals and have more discretion to adjust them to manipulate 
firms' performance. As a result, earnings management has a stronger impact on accruals than on operating cash flows (Wang et al., 2015). Since accruals are more severely affected by earnings management activities, they should have lower predictive power than operating cash flows. The empirical findings of Wang et al. (2015) confirm this expectation.

This study posits the logical reasoning of Wang et al. (2015) that the predictive power of operating cash flows differs from that of the accruals. This study argues by comparing accounting and financial management measurement. The hypothesis $\mathrm{H} 4$ uses the financial management perspective that it is firms' operating cash flows. This aggregate firms' operating cash flow derived from real operations to produce merchandise and services to customers. Furthermore, they could determine the future GDP growths because without management modification, which is called earnings management (manipulations) in the accounting discipline. It would probably reflect the future GDP growth better than the accounting one because it is without manipulation of calculation. Therefore, this study investigates operating cash flows to predict the future GDP growths in the following hypothesis.

\section{H4. Aggregate operating cash flows affect the future GDP growths positively.}

This study continues by recalling from the argument of hypothesis $\mathrm{H} 4$ to construct that of hypothesis H5. It argues that deferrals and accruals accounting could forecast the future GDP growth. Both deferrals and accruals could probably explain remaining variances of the future GDP growths. Meanwhile, this study argues that firms' management had policies to sacrifice some discretionary costs or expenses supporting to produce goods. They usually are period and immediate' costs that accounting assigns them by allocating systematically. The firms' management needs deferrals and accruals to accomplish the other activities that the management cannot induce them to the productions' costs. This means that the other remaining costs could forecast the future GDP growths. Therefore, this study investigates both deferrals and accruals to predict the future GDP growths in the following hypothesis.

\section{H5. Aggregate deferrals and accruals affect the future GDP growths positively.}

\section{Methodological approach}

\subsection{Population, sample, and unit of analysis}

The population of this study is all countries in the world. According to The Worldbank data, there are 215 countries (http://data.worldbank.org/indicator/NY.GDP.MKTP. CD). This study selects samples based on the existence of stock exchanges in every country, the completeness of the data requirements, the numbers of listed companies in the stock exchange that it is not less than 30 companies, and the country has no extremely outlier data. This research obtains 57 countries whose stock exchange has more than 30 companies with complete accounting data. From the 57 countries, this study excludes two countries because they do not have GDP data. It also drops 11 countries as they indicate extremely outlier data. Finally, this study collects 44 countries (Appendix 1 presents the country names).

This study uses nation-year as the unit of analysis. Notation $(i)$ is the total aggregate of accounting earnings and its components. It is the sum of the listed companies' accounting earnings and their components on the countries' stock exchanges. Year $(t)$ represents time by time consecutively. 


\subsection{Data}

This research uses accounting numbers and a macroeconomy indicator as the data. Accounting numbers consist of annual net income and its components, namely operating income, non-operating income, operating cash flows, and accruals. This study obtains accounting numbers data from the OSIRIS database available at Universitas Gadjah Mada, Indonesia (https://osiris.bvdinfo.com). This study uses a macroeconomy indicator, the GDP growths, taken from The Worldbank website (http://data.worldbank.org/indicator/NY.GDP.

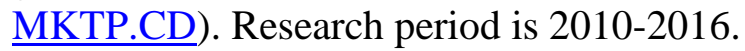

\subsection{Variables and their measurement}

This study employs dependent variables that are one- and two years ahead of the future GDP growths $\left(G D P_{i t+1}\right.$ and $\left.G D P_{i t+2}\right)$. It correspondingly employs five independent variables, namely aggregate net income $\left(N I_{i t}\right)$, aggregate operating income $\left(O I_{i t}\right)$, aggregate non-operating income $\left(N O_{i t}\right)$, aggregate operating cash flows $\left(C F O_{i t}\right)$, and aggregate accruals $\left(A C C_{i t}\right)$. Meanwhile, this research uses the level of macroeconomic development $\left(E C_{i t}\right)$ and earnings quality $\left(E Q_{i t}\right)$ as robustness test variables.

This study determines and calculates variables of a company's accounting number suited for data classification and availability in industrial templates of the OSIRIS database. Net income and operating income are items with the codes of 13045 and 13022 respectively. This research calculates non-operating income as the sum of financial P/L (13027) and other non-operating/financial income/expense (22080). This study calculates accruals determined by using the formula of Ball and Shivakumar (2005) as follows:

Accrual $=\Delta$ Inventory $+\Delta$ Debtors $+\Delta$ Other current assets $-\Delta C r e d i t o r-$

- $\Delta$ Other current liabilities - Depreciation

Based on OSIRIS database structures, inventories, trade accounts receivable, other current assets, accounts payable, other current liabilities, and depreciation are items with the codes of 20010, 13052, 20050, 21020, 21055, and 13021 respectively. Operating cash flows are measured by subtracting accruals from net income. Meanwhile, this study converts the measurement basis from company level to aggregate level as the sum of accounting numbers of all companies listed on the stock exchange for each country. Accounting numbers are scaled by total aggregate assets $\left(\mathrm{TA}_{i t}\right)$, which is an item with the code of 13077 , to avoid the bias of size's differences in each country's stock exchange.

The level of macroeconomic development is a dummy variable, with " 1 " if a country is a developing and " 0 " if it is a developed country. This study classifies a country to be developed or developing country based on its economic condition that is consistent to the classification of the Department of Economic and Social Affairs of the United Nations Secretariat (UN/DESA). This study, then, reconfirms to the country's GDP level that is according to the classification of the World Bank. UN/DESA classifies all countries in the world into one of three broad categories, i.e., developed economies, economies in transition, and developing economies (www.un.org/en/development/.../2014wesp_country_classification.pd). In the meantime, based on the GDP level of each country, the Wordbank classifies those countries into four categories, i.e., countries with high income, upper middle income, lower middle income, and low income (http://data.worldbank.org/indicator/NY. GDP.MKTP.CD). This study categorises a country as a developed country if it is classified as developed economies by UN/DESA and high-income nations according to the Worldbank. Instead, this study categorises a country as a 
developing country if it is a developing economy by DPAD of UN/DESA and upper middle income, lower middle income, or low-income nation according to the Worldbank.

The earnings quality variable is a dummy variable, with "1" represents high earnings quality and " 0 " stands for low earnings quality. This research employs earnings persistence as a proxy for earnings quality (P. Dechow et al., 2010). This study estimates the degree of earnings quality as the $\beta$-coefficient of a cross-sectional autoregressive equation of net income for each country. Furthermore, it split the degree of earnings quality across research observations (nation-year) into two groups based on their median value. The first group is a high earnings quality subsample, consisting of observations whose $\beta$-coefficient is higher than their median. Meanwhile, the second one is a low earnings quality subsample, containing observations with a $\beta$-coefficient lower than their median.

\subsection{Hypotheses testing}

This study employs multiple linear regression analysis to investigate the predictive power of aggregate corporate earnings on the future GDP growths. It assumes that this association is linear. Then, the regression equation is as follows:

$$
G D P_{i t+j}=\alpha+\beta_{1} N I_{i t}+\beta_{2} E C_{i t}+\beta_{3} E Q_{i t}+\varepsilon_{i t}
$$

In the regression equation (2), GDP $i t+j$ is the GDP growth of country $i$ in year $t+j(j=1$, 2 ) and $N I_{i t}$ is the aggregate net income of country $i$ in the year $t$. Meanwhile, $E C_{i t}$ is a dummy variable with " 1 " if country $i$ in the year $t$ is a developing country and " 0 " if it is a developed country. $E Q_{i t}$ is also a dummy variable with a value of " 1 " if country $i$ in the year $t$ has a high earnings quality and " 0 " if it has a low one. This study expects that $\beta_{l}$ should be positively significant at the level of $5 \%$ for the period $t+j(j=1,2)$, which indicates aggregate net income can predict GDP growth for one- and two-years ahead.

This study, furthermore, examines the power of aggregate earnings components to predict the future GDP growths by disaggregating components of earnings based on their degree of operating and non-operating incomes permanence. Formula (3) is the regression equation used to investigate such predictive powers:

$$
G D P_{i t+j}=\alpha+\beta_{1} O I_{i t}+\beta_{2} N O_{i t}+\beta_{3} E C_{i t}+\beta_{4} E Q_{i t}+\varepsilon_{i t}
$$

In the regression equation (3), $O I_{i t}$ is the aggregate operating income of country $i$ in the year $t$, while $N O_{i t}$ is the aggregate non-operating income of country $i$ in the year $t$. The positive values of $\beta_{1}$ and $\beta_{2}$ coefficients should be significant at the level of $1 \%, 5 \%$, or $10 \%$ for the period $t+j(j=1,2)$. The significances indicate that aggregate operating and non-operating incomes have predictive power to the future GDP growths for one- and two-years ahead.

On the other side, this research decomposes aggregate net income into aggregate operating cash flows and accruals. This study examines the predictive content of these two components because earnings management affects them distinctively. Regression equation denoted in formula (4) tests the predictive ability:

$$
G D P_{i t+j}=\alpha+\beta_{1} C F O_{i t}+\beta_{2} A C C_{i t}+\beta_{3} E C_{i t}+\beta_{4} E Q_{i t}+\varepsilon_{i t}
$$

In the regression equation (4), $C F O_{i t}$ is the aggregate operating cash flows of country $i$ in the year $t$, while $A C C_{i t}$ is the aggregate accruals of country $i$ in the year $t$. The positive values 
of $\beta_{1}$ and $\beta_{2}$ coefficients should be significant at the level of $1 \%, 5 \%$, or $10 \%$ for the period $t+j$ $(j=1,2)$. It indicates that aggregate operating cash flows and accruals have a predictive content to predict the future GDP growths for one- and two-years ahead.

\subsection{Additional analysis}

This study conducts additional analysis to explore the effect of country-specific factors on the ability of aggregate corporate earnings and its disaggregation to predict the future GDP growths. The additional analysis compares the predictive content of aggregate corporate earnings and their components in developed countries to those in developing countries as well as compares observations with high and low earnings quality.

For that purpose, this study splits the sample into two subsamples based on the level of macroeconomic development, which are developed and developing country subsamples. The data of each subsample are separately analysed using regression equations (5), (6), and (7):

$$
\begin{aligned}
& G D P_{i t+j}=\alpha+\beta_{1} N I_{i t}+\beta_{2} E Q_{i t}+\varepsilon_{i t} \\
& G D P_{i t+j}=\alpha+\beta_{1} O I_{i t}+\beta_{2} N O_{i t}+\beta_{3} E Q_{i t}+\varepsilon_{i t} \\
& G D P_{i t+j}=\alpha+\beta_{1} C F O_{i t}+\beta_{2} A C C_{i t}+\beta_{3} E Q_{i t}+\varepsilon_{i t}
\end{aligned}
$$

Data analysis of each subsample with regression equation (5) yields two coefficient values of aggregate net income, i.e., the coefficient for developed $\left(\beta_{l M}\right)$ and developing $\left(\beta_{l K}\right)$ countries. These two coefficients reflect the degree of aggregate net income ability of developed and developing countries to predict the future GDP growths. The regression equations (6) and (7), applied to each subsample and resulted in two coefficient values each.

This study further investigates whether the predictive content of aggregate net income and aggregate earnings components of developed countries is different from that of developing countries. This research conducts a t-test for comparing the coefficients across regression equations to infer whether or not there is different predictive ability. Formula (8) presents the equation for determining t-statistics based on the formula as follows.

$$
t=\frac{\beta_{1 D}-\beta_{1 U}}{\sqrt{\frac{S S E_{D}+S S E_{U}}{d f_{D}+d f_{U}} \cdot\left[\frac{\left(\beta_{D}\right)^{2} \cdot d f_{D}}{\left(t_{D}\right)^{2} \cdot S S E_{D}}+\frac{\left(\beta_{1 U}\right)^{2} \cdot d f_{U}}{\left(t_{U}\right)^{2} \cdot S S E_{U}}\right]}}
$$

In equation (8), SSE is a sum of the squared error of the regression and $d f$ is degrees of freedom. Subscripts $D$ and $U$ refer to developed and developing countries subsamples.

This study also splits the research sample into two subsamples based on the degree of earnings quality, i.e., high and low earnings quality subsamples. The data of each subsample are separately analysed using the following regression equation:

$$
\begin{aligned}
& G D P_{i t+j}=\alpha+\beta_{1} N I_{i t}+\beta_{2} E C_{i t}+\varepsilon_{i t} \\
& G D P_{i t+j}=\alpha+\beta_{1} O I_{i t}+\beta_{2} N O_{i t}+\beta_{3} E C_{i t}+\varepsilon_{i t} \\
& G D P_{i t+j}=\alpha+\beta_{1} C F O_{i t}+\beta_{2} A C C_{i t}+\beta_{3} E C_{i t}+\varepsilon_{i t}
\end{aligned}
$$

Data analysis of each subsample using regression equation (9) results in two coefficient values of aggregate net income, i.e., the coefficient for a high earnings quality subsample $\left(\beta_{l T}\right)$ and low earnings quality subsample $\left(\beta_{l R}\right)$. These two coefficients reflect the degree of aggregate net income ability of high and low earnings quality observations in predicting the GDP growth. 
The regression equations (10) and (11), applied to each subsample, also result in two coefficient values.

This study runs a t-test to compare coefficients across regression equations. This function is to conclude whether the predictive power of aggregate net income and its components of high earnings quality subsample are statistically different from that the low one. Consistent with equation (8), the equation exhibited in formula (12) determines the t-statistics. Subscripts $H$ and $L$ show subsample of the high and low earnings qualities consecutively.

$$
t=\frac{\beta_{1 H}-\beta_{1 L}}{\sqrt{\frac{S S E_{H}+S S E_{L}}{d f_{H}+d f_{L}} \cdot\left[\frac{\left(\beta_{1 H}\right)^{2} \cdot d f_{H}}{\left(t_{H}\right)^{2} \cdot S S E_{H}}+\frac{\left(\beta_{1 L}\right)^{2} \cdot d f_{L}}{\left(t_{L}\right)^{2} \cdot S S E_{L}}\right]}}
$$

\section{Conducting research and results}

\subsection{Descriptive statistics}

Table 1 presents descriptions of the research sample. The number of observations is 264 , that is to say, a nation-year unit of analysis. The results of the descriptive statistical analysis show that the mean value of the GDP growth is positive. They are 0.02858 and 0.03020 for the mean of the $G D P_{i t+2}$ and $G D P_{i t+1}$ respectively. It indicates that on average, there is an increase in the countries' GDP rates.

Table 1. Descriptive Statistics

\begin{tabular}{|c|c|c|c|c|c|}
\hline Variables & Mean & Minimum & Median & Maximum & Stand. Dev. \\
\hline$G D P_{i t+2}$ & 0.02858 & -0.02928 & 0.02648 & 0.09332 & 0.02351 \\
\hline$G D P_{i t+1}$ & 0.03020 & -0.02928 & 0.02684 & 0.11114 & 0.02487 \\
\hline$N I_{i t}$ & 0.04059 & -0.01645 & 0.03965 & 0.18508 & 0.02294 \\
\hline$O I_{i t}$ & 0.03299 & 0.00599 & 0.02426 & 0.12184 & 0.02455 \\
\hline$N O_{i t}$ & -0.00489 & -0.02716 & -0.00353 & 0.01797 & 0.00604 \\
\hline$C F O_{i t}$ & 0.04196 & -0.22886 & 0.03642 & 0.37133 & 0.04569 \\
\hline$A C C_{i t}$ & -0.00164 & -0.30166 & -0.00051 & 0.28874 & 0.04008 \\
\hline$E C_{i t}$ & 0.45455 & 0.00000 & 0.00000 & 1.00000 & 0.49888 \\
\hline$E Q_{i t}$ & 0.50000 & 0.00000 & 0.50000 & 1.00000 & 0.50095 \\
\hline
\end{tabular}

Notes:

Number of observations $=264$.

$G D P_{i t+2}=G D P$ growth of country $i$ in year $t+2 ; G D P_{i t+1}=G D P$ growth of country $i$ in year $t+1 ; N I_{i t}=$ aggregate net income of country $i$ year $t ; I_{i}=$ aggregate operating income of country $i$ year $t ;$ NO it $_{1}=$ aggregate non-operating income of country $i$ year $t ; C_{i t}=$ aggregate operating cash flows of country $i$ year $t ; A C C_{i t}=$ aggregate accruals of country $i$ year $t$; EC $C_{i t}=$ macroeconomic development level of country $i$ year $t$ (dummy variable, $1=$ developing country, $0=$ developed country); $E Q_{i t}=$ earnings quality degree of country $i$ year $t$ (dummy variable, $1=$ high earnings quality, $0=$ low earnings quality).

\subsection{Hypotheses test results}

This study hypothesises that aggregate net incomes $\left(\mathrm{H}_{1}\right)$ and their components $\left(\mathrm{H}_{2}-\mathrm{H}_{5}\right)$ can predict the future GDP growths for one- and two-years ahead. This study executes hypotheses testing by multiple linear regression analysis in the equations (2), (3), and (4). Table 2 shows the hypotheses test results. For example, the aggregate corporate net income $\left(N I_{i t}\right)$ can predict the one-year-ahead GDP growth $(N I \beta$-coefficient $=0.27550$, $p$-value $<1 \%)$. It predicts the future GDP growths $\left(G D P_{i t+1}\right)$ differently for the developed countries in comparison to the developing countries $(E C \beta$-coefficient $=0.01242$, $p$-value $<1 \%)$. The prediction also differs 
for the high (low) earning qualities (EQ $\beta$-coefficient $=0.00803$, $p$-value $<1 \%)$. Based on the hypotheses test results presented in Table 2, this study succeeds in supporting all hypotheses proposed, except for hypothesis $\mathrm{H}_{3}$, for both the time horizons of one- and two-years ahead.

Table 2. Hypotheses Test Results

\begin{tabular}{|c|c|c|c|c|c|c|c|}
\hline \multicolumn{8}{|c|}{ Panel A: $G D P_{i t+j}=\alpha+\beta_{1} N I_{i t}+\beta_{2} E C_{i t}+\beta_{3} E Q_{i t}+\varepsilon_{i t}$} \\
\hline \multirow{2}{*}{ Variables } & \multirow{2}{*}{ Prediction } & \multicolumn{3}{|c|}{$j=1$} & \multicolumn{3}{|c|}{$j=2$} \\
\hline & & coefficients & t-statistics & & coefficients & t-statistics & \\
\hline$C$ & & 0.00936 & 3.28430 & $* * *$ & 0.00969 & 3.18952 & $* * *$ \\
\hline$N I_{i t}$ & + & 0.27550 & 4.15503 & $* * *$ & 0.23987 & 3.56961 & $* * *$ \\
\hline$E C_{i t}$ & & 0.01242 & 4.22064 & $* * *$ & 0.01264 & 4.06363 & $* * *$ \\
\hline \multirow[t]{4}{*}{$E Q_{i t}$} & & 0.00803 & 2.85932 & $* * *$ & 0.00602 & 2.08139 & $*$ \\
\hline & & $R$-squared $=$ & \multirow{3}{*}{\multicolumn{2}{|c|}{$\begin{array}{l}0.234 \\
0.225 \\
26.509 * * *\end{array}$}} & $R$-squared $=$ & \multirow{3}{*}{\multicolumn{2}{|c|}{$\begin{array}{l}0.219 \\
0.208 \\
20.203 * * * \\
\end{array}$}} \\
\hline & & Adj $R$-squared $=$ & & & Adj $R$-squared $=$ & & \\
\hline & & $F$-statistics $=$ & & & $F$-statistics $=$ & & \\
\hline \multicolumn{8}{|c|}{ Panel B: $G D P_{i t+j}=\alpha+\beta_{l} O I_{i t}+\beta_{2} N O_{i t}+\beta_{3} E C_{i t}+\beta_{4} E Q_{i t}+\varepsilon_{i t}$} \\
\hline \multirow{2}{*}{ Variables } & \multirow{2}{*}{ Prediction } & \multicolumn{3}{|c|}{$j=1$} & \multicolumn{3}{|c|}{$j=2$} \\
\hline & & coefficients & t-statistics & & coefficients & t-statistics & \\
\hline$C$ & & 0.01307 & 4.93218 & $* * *$ & 0.01459 & 5.17252 & $* * *$ \\
\hline$O I_{i t}$ & + & 0.21689 & 3.50774 & $* * *$ & 0.13335 & 2.12452 & $*$ \\
\hline$N O_{i t}$ & + & 0.32243 & 1.29592 & & 0.31730 & 1.23031 & \\
\hline$E C_{i t}$ & & 0.01584 & 5.49971 & $* * *$ & 0.01657 & 5.45344 & $* * *$ \\
\hline \multirow[t]{4}{*}{$E Q_{i t}$} & & 0.00870 & 3.07585 & $* * *$ & 0.00680 & 2.29779 & $* *$ \\
\hline & & $R$-squared $=$ & \multirow{3}{*}{\multicolumn{2}{|c|}{$\begin{array}{l}0.220 \\
0.208 \\
18.314 * * *\end{array}$}} & $R$-squared $=$ & \multirow{3}{*}{\multicolumn{2}{|c|}{$\begin{array}{l}0.191 \\
0.176 \\
12.697 * * *\end{array}$}} \\
\hline & & Adj $R$-squared $=$ & & & Adj $R$-squared $=$ & & \\
\hline & & $F$-statistics $=$ & & & $F$-statistics $=$ & & \\
\hline \multicolumn{8}{|c|}{ Panel C: $G D P_{i t+j}=\alpha+\beta_{l} C F O_{i t}+\beta_{2} A C C_{i t}+\beta_{3} E C_{i t}+\beta_{4} E Q_{i t}+\varepsilon_{i t}$} \\
\hline \multirow{2}{*}{ Variables } & \multirow{2}{*}{ Prediction } & \multicolumn{3}{|c|}{$j=1$} & \multicolumn{3}{|c|}{$j=2$} \\
\hline & & coefficients & t-statistics & & coefficients & t-statistics & \\
\hline$C$ & & 0.00991 & 3.486 & $* * *$ & 0.01015 & 3.35727 & $* * *$ \\
\hline$C F O_{i t}$ & + & 0.26076 & 3.919 & $* * *$ & 0.23082 & 3.42638 & $* * *$ \\
\hline$A C C_{i t}$ & + & 0.26555 & 3.576 & $* * *$ & 0.25421 & 3.30759 & $* * *$ \\
\hline$E C_{i t}$ & & 0.01253 & 4.219 & $* * *$ & 0.01262 & 4.02296 & $* * *$ \\
\hline \multirow[t]{4}{*}{$E Q_{i t}$} & & 0.00818 & 2.895 & $* * *$ & 0.00601 & 2.06430 & $*$ \\
\hline & & $R$-squared $=$ & 0.229 & & $R$-squared $=$ & 0.217 & \\
\hline & & Adj $R$-squared $=$ & 0.217 & & Adj $R$-squared $=$ & 0.202 & \\
\hline & & $F$-statistics $=$ & $19.253 * * *$ & & $F$-statistics $=$ & $14.888 * * *$ & \\
\hline
\end{tabular}

Notes:

$G D P_{i t+2}=G D P$ growth of country $i$ in year $t+2 ; G D P_{i t+1}=G D P$ growth of country $i$ in year $t+1 ; N I_{i t}=$ aggregate net income of country $i$ year $t ; \mathrm{I}_{i}=$ aggregate operating income of country $i$ year $t ; \mathrm{O}_{i t}=$ aggregate non-operating income of country $i$ year $t ; C_{i t}=$ aggregate operating cash flows of country $i$ year $t ; A C C_{i t}=$ aggregate accruals of country $i$ year $t$; $E C_{i t}=$ macroeconomic development level of country $i$ year $t$ (dummy variable, $1=$ developing country, $0=$ developed country); $E Q_{i t}=$ earnings quality degree of country $i$ year $t$ (dummy variable, $1=$ high earnings quality, $0=$ low earnings quality).

$* * *, * *$, and $*$ significant at the level of $1 \%, 5 \%$, and $10 \%$ respectively

\subsection{Additional analysis results}

This study performs additional sensitivity tests. It is intended to support the fundamental logic regarding whether all types of accounting variables could explain the GDP growth in other conditional factors. This study reasonably mentions that other variables or factors influence the forecast of GDP growth and formation, especially whether countries have "developeddeveloping countries" and "high-low earnings quality." Therefore, this study conducts additional analysis to explore the effect of country-specific factors that the aggregate corporate 
earnings and their components could predict the future GDP growths. Therefore, this research splits the sample based on the level of macroeconomic development and the degree of earnings quality. Table 3 shows descriptive statistics for each subsample. The number of observations for developed, developing, high earnings, and low earnings quality subsamples are 144, 120, 132 , and 132, respectively. The results of descriptive statistical analysis demonstrate that the future GDP growths of developing countries are higher than those of the developed countries. For example, Table 3 shows that the mean of the future GDP growths $\left(G D P_{i t+1}\right)$ for the developing countries is 0.04015 , while for the developed countries is 0.02190 . This is consistent with the characteristics of developing countries, which are undergoing economic growth.

Table 3. Descriptive Statistics of Subsamples

\begin{tabular}{|c|c|c|c|c|c|c|c|c|c|c|}
\hline \multicolumn{11}{|c|}{ Panel A: Subsamples based on the level of macroeconomy development } \\
\hline & \multicolumn{5}{|c|}{$\begin{array}{l}\text { Developed Country Subsample } \\
\qquad(\mathrm{N}=144)\end{array}$} & \multicolumn{5}{|c|}{$\begin{array}{l}\text { Developing Country Subsample } \\
\qquad(\mathrm{N}=120)\end{array}$} \\
\hline & Mean & Min & Median & Max & SD & Mean & Min & Median & Max & SD \\
\hline$G D P_{i t+2}$ & 0.020 & -0.029 & & & 0.018 & & -0.028 & & & 0.026 \\
\hline$G D P_{i t+1}$ & 0.022 & -0.029 & 0.020 & 0.100 & 0.019 & 0.040 & -0.028 & 0.044 & 0.111 & 0.027 \\
\hline$N I_{i t}$ & 0.032 & -0.002 & 0.029 & 0.077 & 0.017 & 0.050 & -0.016 & 0.047 & 0.185 & 0.025 \\
\hline$O I_{i t}$ & 0.028 & 0.006 & 0.021 & 0.097 & 0.020 & 0.039 & 0.006 & 0.030 & 0.122 & 0.028 \\
\hline$N O_{i t}$ & -0.003 & -0.027 & -0.003 & 0.018 & 0.006 & -0.007 & -0.027 & -0.004 & 0.008 & 0.006 \\
\hline$C F O_{i t}$ & 0.035 & -0.061 & 0.028 & 0.179 & 0.032 & 0.051 & -0.229 & 0.046 & 0.371 & 0.057 \\
\hline$A C C_{i t}$ & -0.003 & -0.152 & -0.001 & 0.090 & 0.029 & 0.000 & -0.302 & 0.001 & 0.289 & 0.050 \\
\hline$E Q_{i t}$ & 0.451 & 0.000 & 0.000 & 1.000 & 0.499 & 0.558 & 0.000 & 1.000 & 1.000 & 0.499 \\
\hline
\end{tabular}

Panel B: Subsamples based on the degree of earnings quality

\begin{tabular}{|c|c|c|c|c|c|c|c|c|c|c|}
\hline & \multicolumn{5}{|c|}{$\begin{array}{l}\text { High Earnings Quality Subsample } \\
\qquad(\mathrm{N}=132)\end{array}$} & \multicolumn{5}{|c|}{$\begin{array}{l}\text { Low Earnings Quality Subsample } \\
\qquad(\mathrm{N}=132)\end{array}$} \\
\hline & Mean & Min & Median & Max & SD & Mean & Min & Median & Max & SD \\
\hline$G D P_{i t+2}$ & 0.033 & -0.029 & 0.029 & 0.093 & 0.024 & 0.024 & -0.028 & 0.023 & 0.091 & 0.023 \\
\hline$G D P_{i t+1}$ & 0.037 & -0.025 & 0.033 & 0.111 & 0.026 & 0.024 & -0.029 & 0.024 & 0.084 & 0.022 \\
\hline$N I_{i t}$ & 0.047 & -0.016 & 0.046 & 0.106 & 0.022 & 0.034 & -0.007 & 0.031 & 0.185 & 0.022 \\
\hline$O I_{i t}$ & 0.038 & 0.007 & 0.029 & 0.122 & 0.0 & 0.028 & 0.006 & 0.021 & 0.106 & 0.020 \\
\hline$N O_{i t}$ & -0.005 & -0.027 & -0.003 & 0.018 & 0.006 & -0.005 & -0.027 & -0.004 & 0.018 & 0.006 \\
\hline$C F O_{i t}$ & 0.048 & -0.061 & 0.040 & 0.231 & 0.038 & 0.036 & -0.229 & 0.030 & 0.371 & 0.052 \\
\hline$A C C_{i t}$ & -0.001 & -0.152 & 0.001 & 0.090 & 0.032 & -0.002 & -0.302 & -0.002 & 0.289 & 0.047 \\
\hline$E C_{i t}$ & 0.508 & 0.000 & 1.000 & 1.000 & 0.502 & 0.402 & 0.000 & 0.000 & 1.000 & 0.492 \\
\hline
\end{tabular}

\section{Notes:}

$G D P{ }_{i t+2}=G D P$ growth of country $i$ in year $t+2 ; G D P_{i t+l}=G D P$ growth of country $i$ in year $t+1 ;$ NIt $=$ aggregate net income of country $i$ year $t$; $O I_{i}=$ aggregate operating income of country $i$ year $t ; N O_{i t}=$ aggregate non-operating income of country $i$ year $t ; C F O_{i t}=$ aggregate operating cash flows of country $i$ year $t ; A C C_{i t}=$ aggregate accruals of country $i$ year $t$; $E C_{i t}=$ macroeconomic development level of country $i$ year $t$ (dummy variable, $1=$ developing country, $0=$ developed country); $E Q_{i t}=$ earnings quality degree of country $i$ year $t$ (dummy variable, $1=$ high earnings quality, $0=$ low earnings quality).

This research further investigates whether all hypothesis tests results are consistent within each subsample. Table 4 shows the test results in developed and developing countries subsamples. In the developed countries subsample, this study denotes significant results in aggregate net income, operating cash flows, and accruals both for the one- and two-years ahead. However, aggregate operating income is statistically significant for the one-year-ahead only. In contrast, this study does not find a significant result for aggregate non-operating income. Thus, the statistical results of the developed countries subsample support hypotheses $\mathrm{H}_{1}, \mathrm{H}_{4}$, and $\mathrm{H}_{5}$ for the one- and two-years ahead, hypothesis $\mathrm{H}_{2}$ for the one-year-ahead only, but fail to support hypothesis $\mathrm{H}_{3}$. 
Table 4. Hypotheses Test Results of Developed and Developing Country Subsamples

\begin{tabular}{|c|c|c|c|c|c|c|c|c|c|c|c|c|c|}
\hline \multicolumn{14}{|c|}{ Panel A: $G D P_{i t+j}=\alpha+\beta_{l} N I_{i t}+\beta_{2} E Q_{i t}+\varepsilon_{i t}$} \\
\hline \multirow{3}{*}{ Var. } & \multirow{3}{*}{$\begin{array}{l}\text { Pre- } \\
\text { dic- } \\
\text { tion }\end{array}$} & \multicolumn{6}{|c|}{ Developed Countries } & \multicolumn{6}{|c|}{ Developing Countries } \\
\hline & & \multicolumn{2}{|c|}{$j=1$} & \multicolumn{4}{|c|}{$j=2$} & \multicolumn{2}{|c|}{$j=1$} & \multicolumn{4}{|c|}{$j=2$} \\
\hline & & coeff. & t-stat. & & coeff. & t-stat. & & coeff. & t-stat. & & coeff. & t-stat. & \\
\hline$C$ & \multirow{6}{*}{+} & 0.009 & 2.851 & $* * *$ & 0.007 & 2.203 & $*$ & 0.021 & 3.733 & $* * *$ & 0.024 & 3.885 & $* * *$ \\
\hline$N I_{i t}$ & & 0.339 & 3.592 & $* * *$ & 0.341 & 3.696 & $* * *$ & 0.245 & 2.566 & $* *$ & 0.192 & 1.930 & \\
\hline \multirow{4}{*}{$E Q_{i t}$} & & 0.004 & 1.091 & & 0.004 & 1.167 & & 0.013 & 2.678 & $* *$ & 0.008 & 1.543 & \\
\hline & & $R^{2}=$ & 0.119 & & $R^{2}=$ & 0.142 & & $R^{2}=$ & 0.129 & & $R^{2}=$ & 0.07 & \\
\hline & & $\operatorname{Adj} R^{2}=$ & 0.106 & & $\operatorname{Adj} R^{2}=$ & 0.127 & & $\operatorname{Adj} R^{2}=$ & 0.114 & & $\operatorname{Adj} R^{2}=$ & 0.05 & \\
\hline & & $F$-stat $=$ & $9.502 * * *$ & & $F$-stat. $=$ & $9.692 * * *$ & & $F$-stat. $=$ & $8.665 * * *$ & & $F$-stat. $=$ & $3.552 * *$ & \\
\hline \multicolumn{14}{|c|}{ Panel B: $G D P_{i t+j}=\alpha+\beta_{l} O I_{i t}+\beta_{2} N O_{i t}+\beta_{3} E Q_{i t}+\varepsilon_{i t}$} \\
\hline \multirow{3}{*}{ Var. } & Pre- & \multicolumn{6}{|c|}{ Developed Countries } & \multicolumn{6}{|c|}{ Developing Countries } \\
\hline & dic- & \multicolumn{2}{|c|}{$j=1$} & \multicolumn{4}{|c|}{$j=2$} & \multicolumn{2}{|c|}{$j=1$} & \multicolumn{4}{|c|}{$j=2$} \\
\hline & tion & coeff. & t-stat. & & coeff. & t-stat. & & coeff. & t-stat. & & coeff. & t-stat. & \\
\hline$C$ & & 0.012 & 4.381 & $* * *$ & 0.013 & 4.431 & **** & 0.030 & 6.180 & $* * *$ & 0.035 & 6.652 & **** \\
\hline$O I_{i t}$ & + & 0.215 & 2.636 & $* *$ & 0.095 & 1.195 & & 0.247 & 2.653 & $* * *$ & 0.187 & 1.961 & \\
\hline$N O_{i t}$ & + & -0.298 & -1.030 & & -0.493 & -1.669 & & 0.933 & 2.253 & $*$ & 1.085 & 2.562 & $* *$ \\
\hline \multirow[t]{4}{*}{$E Q_{i t}$} & & 0.006 & 1.722 & & 0.006 & 1.990 & $*$ & 0.011 & 2.328 & $* *$ & 0.006 & 1.183 & \\
\hline & & $R^{2}=$ & 0.101 & & $R^{2}=$ & 0.088 & & $R^{2}=$ & 0.144 & & $R^{2}=$ & 0.1 & \\
\hline & & $\operatorname{Adj} R^{2}=$ & 0.083 & & $\operatorname{Adj} R^{2}=$ & 0.064 & & $\operatorname{Adj} R^{2}=$ & 0.122 & & $\operatorname{Adj} R^{2}=$ & 0.08 & \\
\hline & & $F$-stat. $=$ & $5.288 * * *$ & & $F-$ stat. $=$ & $3.711 * * *$ & & $F$-stat. $=$ & $6.523 * * *$ & & $F$-stat. $=$ & $3.699 * *$ & \\
\hline \multicolumn{14}{|c|}{ Panel C: $G D P_{i t+j}=\alpha+\beta_{l} C F O_{i t}+\beta_{2} A C C_{i t}+\beta_{3} E Q_{i t}+\varepsilon_{i t}$} \\
\hline \multirow{3}{*}{ Var. } & Pre- & \multicolumn{6}{|c|}{ Developed Countries } & \multicolumn{6}{|c|}{ Developing Countries } \\
\hline & dic- & \multicolumn{2}{|c|}{$j=1$} & \multicolumn{4}{|c|}{$j=2$} & $j=$ & & & $j=$ & & \\
\hline & tion & coeff. & t-stat. & & coeff. & t-stat. & & coeff. & t-stat. & & coeff. & t-stat. & \\
\hline$C$ & & 0.010 & 3.168 & $* * *$ & 0.008 & 2.472 & *** & 0.021 & 3.703 & $* * *$ & 0.023 & 3.783 & $* * *$ \\
\hline$C F O_{i t}$ & + & 0.299 & 3.131 & $* * *$ & 0.309 & 3.320 & $* * *$ & 0.246 & 2.564 & $* *$ & 0.198 & 1.985 & $*$ \\
\hline$A C C_{i t}$ & + & 0.282 & 2.689 & $* *$ & 0.293 & 2.807 & $* * *$ & 0.263 & 2.440 & $* *$ & 0.237 & 2.054 & $*$ \\
\hline$E Q_{i t}$ & & 0.004 & 1.236 & & 0.004 & 1.288 & & 0.013 & 2.680 & $* *$ & 0.008 & 1.558 & \\
\hline & & $R^{2}=$ & 0.101 & & $R^{2}=$ & 0.125 & & $R^{2}=$ & 0.13 & & $R^{2}=$ & 0.07 & \\
\hline & & $\operatorname{Adj} R^{2}=$ & 0.082 & & $\operatorname{Adj} R^{2}=$ & 0.102 & & $\operatorname{Adj} R^{2}=$ & 0.108 & & $\operatorname{Adj} R^{2}=$ & 0.05 & \\
\hline & & $F$-stat. $=$ & $5.247 * * *$ & & $F-$ stat. $=$ & $5.530 * * *$ & & $F$-stat. $=$ & $5.778 * * *$ & & $F$-stat. $=$ & $2.558 * *$ & \\
\hline $\begin{array}{c}\text { Notes } \\
G D P_{i t+} \\
\text { countr } \\
\text { CFO } \\
\text { develo } \\
\text { degree }\end{array}$ &  & $\begin{array}{l}\text { owth o } \\
I_{i t}=a g \\
\text { opera }\end{array}$ & $\begin{array}{l}\text { try } i \text { in } \\
\text { te oper } \\
\text { ash flor }\end{array}$ & of $c$ & $\begin{array}{l}\text { DP } P_{i t+1} \\
\text { e of cou } \\
\text { y i year } \\
\text { able, } 1\end{array}$ & $\begin{array}{l}D P \text { grow } \\
\text { i year } t \\
C C_{i t}=a\end{array}$ & $\begin{array}{l}\mathrm{NO}_{\text {it }} \\
\text { rega } \\
\text { count } \\
=l o\end{array}$ & $\begin{array}{l}\text { try } i \text { in ye } \\
\text { gregate } n \\
\text { ccruals of } \\
=\text { develc } \\
\text { trnings qu }\end{array}$ & $\begin{array}{l}+1 ; I_{i t}= \\
\text { operating } \\
\text { untry } i \text { ye } \\
\text { country) }\end{array}$ & $\begin{array}{l}=\text { agg } \\
\text { g inc } \\
\text { eart; } \\
\text { ); E( }\end{array}$ & $\begin{array}{l}\text { ate net in } \\
\text { of count } \\
{ }_{i t}=\text { macro }\end{array}$ & $\begin{array}{l}\text { year } \\
\text { yeamic } \\
\text { nolity }\end{array}$ & \\
\hline
\end{tabular}

In the developing countries subsample, this study shows significant results in aggregate non-operating income, operating cash flows, and accruals for both the one- and two-years ahead. Aggregate net income and operating income indicate significant results only for the oneyear-ahead. Table 4 (Panel A) shows the result, for example, that the aggregate corporate net income $\left(N I_{i t}\right)$ of developing countries can predict the one-year-ahead GDP growth $(N I \beta$ coefficient $=0.24513$, $p$-value $<5 \%)$. It predicts the future GDP growths $\left(G D P_{i t+1}\right)$ differently for the high earnings quality in comparison with the low one $(E Q \beta$-coefficient $=0.01285$, $p$ value < 5\%). Therefore, the test results of the developing countries subsample support hypotheses $\mathrm{H}_{3}, \mathrm{H}_{4}$, and $\mathrm{H}_{5}$ for one- and two-years ahead and support hypotheses $\mathrm{H}_{1}$ and $\mathrm{H}_{2}$ only for one-year ahead.

Subsequently, this study examines the mean comparison of whether the predictive power of aggregate corporate earnings and their components associate with the future GDP growths. The examination compares developed and developing countries on the same horizon. The t-test formula compares two coefficients across regression equations (equation 8) determining the level of significance. ${ }^{1}$ The significant results indicate the different predictive ability of aggregate earnings and their components between developed and developing countries. However, this study finds significant results only for aggregate non-operating income with a t-statistic of 2.48847 ( $p$-value < 0.01) for the one-year-ahead and that of 3.09928 ( $p$ value $<0.01)$ for the two-years ahead.

${ }^{1}$ This study calculates the t-test value to compare two $\beta$-coefficients across regression equations. 
Table 5 shows the examination results for the high and low earnings quality subsamples. The results find that there are no differences between these two subsamples. This study supports the hypotheses $\mathrm{H}_{1}, \mathrm{H}_{4}$, and $\mathrm{H}_{5}$ for the one- and two years ahead, and the hypothesis $\mathrm{H}_{2}$ for the one-year-ahead only. However, this study fails to support the hypothesis $\mathrm{H}_{3}$ both in the high and low earnings quality subsamples. When performing the t-test to compare the two coefficients across regression equations in the formula (12), this study finds the statistically significant result in aggregate accrual coefficients for the one-year-ahead with the t-statistics of 1.65671 ( $p$-value $<0.1)$.

Table 5. Hypotheses Test Results of High and Low Earnings Quality Subsamples



\subsection{Discussion}

This study finds empirical evidence that aggregate corporate earnings and their components have predictive content at the macroeconomic level. In more detail, the research findings indicate that aggregate corporate earnings, operating income, operating cash flows, and accruals can predict the future GDP growths for one- and two-years ahead. This study infers that the results are consistent with Konchitchki and Patatoukas (2014a) and Konchitchki and Patatoukas (2014b). This means that this study provides empirical evidence regarding the informativeness of accounting earnings and their disaggregation at the macroeconomic level. Moreover, these findings support the statement that earnings components offer incremental information values (Lipe, 1986). These findings also conclude that findings conclude that 
earnings components are the most critical numbers used to predict future performance (Bratten, 2009). Nevertheless, this study does not find evidence that aggregate non-operating income is a good predictor for the future GDP growths. This is most likely due to non-operating income is a non-recurring item with a low degree of permanence. This finding confirms Griffin (1977) suggesting that the permanence degree of earnings components affects their predictive power. These findings are also consistent with the expectation that the information content of an aggregate non-operating income is different from that of an operating one. Therefore, this study concludes that it not only supports Konchitchki and Patatoukas (2014a) and Konchitchki and Patatoukas (2014b) but also champions the corporate earnings disaggregations as the excellent predictor of the future GDP growths.

This study also finds empirical evidence of the usefulness of accounting earnings and their components at the macroeconomic level for both the developed and developing countries. In both groups of countries, aggregate operating cash flows and accruals are leading indicators of the GDP growth for one and two years ahead, while aggregate operating income is only for one-year ahead. This study also finds that aggregate corporate earnings have predictive power with longer horizons in the developed countries than that in the developing ones. In the developed countries, aggregate earnings can predict GDP growth for one and two years ahead, while in the developing countries this ability is only valid for the subsequent year. In the meantime, aggregate non-operating income can predict the GDP growth only in the developing countries. This finding has consequences for the researcher's motivation that analysis is needed to identify genuinely what factors cause it. Is it because the proportion of firms' total income that is made up of non-operating income in the developing countries is higher than that in the developed ones? This question opens new opportunities for future research.

Furthermore, this study finds that the usefulness of earnings and their components at the macroeconomic level also apply both in high and low earnings quality observations. There are no different findings in the groups; in both, aggregate corporate earnings, operating cash flows, and accruals are good predictors of the future GDP growths for one and two years ahead. However, aggregate operating earnings are good predictors of one-year-ahead GDP growths. Meanwhile, aggregate non-operating income is not a good predictor of the future GDP growths. Nonetheless, when this study compares the predictive power of each component of earnings, it finds an apparent difference between aggregate operating cash flows and accruals. The aggregate accruals' degree of predictive ability is higher (lower) than that of the operating cash flows' in the high (low) earnings quality in the same time horizon. Furthermore, the aggregate accruals' degree of predictive ability in high earnings quality goes beyond that of the low one for a one-year time horizon. It is consistent with Wang et al. (2015) who find evidence that operating cash flows have predictive power for the future GDP growths over longer time horizons than accruals do for all firms listed in Chinese stock exchange. Wang et al. (2015) also represent institutional settings with a high level of earnings management or low level of earnings quality.

The findings of this research generally imply that researchers and practitioners interested in predicting macroeconomic indicators such as GDP growths can use microdata by using the corporate accounting numbers as leading predictors. They can employ both aggregate corporate earnings as well as their components. If they utilise earnings components data, it is better for them to choose earnings components having a higher degree of permanence. Aside from this, they should also consider the level of macroeconomic development of the country. Such concerns are essential since this research reveals that the predictive content of aggregate corporate earnings and their components differ between developed and developing countries. This study finds different predictive power in aggregate non-operating income. Researchers and 
practitioners can use this component to predict the GDP growths for the developing countries, but not that for the developed countries.

Researchers and practitioners should also consider the degree of earnings quality. This degree affects the types of aggregate earnings components that are more appropriate to use, whether they would be aggregate operating cash flows or aggregate accruals. The research findings suggest that researchers and practitioners are encouraged to use aggregate accruals as predictors in high earnings quality contexts since their predictive power goes beyond aggregate operating cash flows. Conversely, they can choose aggregate operating cash flows in the context of low earnings quality because their predictive power is higher than that of the aggregate accruals.

This study suggests that prediction of the future GDP growths could use not only the aggregate corporate earnings but also its disaggregated components. Both the aggregate corporate earnings and their disaggregated components support the conservative predictions. It means that earnings and their components could give the lower and upper limits when they use them to predict the future GDP growths. Furthermore, it means that the novelty finding of this study is that the corporate earnings and their disaggregations are the excellent predictors of the future GDP growths. At least, the use of both aggregate corporate earnings and their disaggregated components could control what economists usually do to predict the future GDP growths.

Overall, the study's results confirm the previous research findings regarding the usefulness of microdata to predict macro indicators. This study discovers that earnings components also have predictive content at the macroeconomy level. This study's findings also indicate the importance of considering country-specific factors, especially when researchers and practitioners conduct predictions in an international setting.

\section{Conclusion}

This research has main objectives that it investigates the usefulness of aggregate corporate earnings and their components to predict the future GDP growths. This investigation is for one- and two years ahead of the future GDP growths. This study finds empirical evidence of the informativeness of aggregate accounting earnings and their components at the macroeconomy level. The study's findings indicate that aggregate corporate earnings, operating income, operating cash flows, and accruals could predict the future GDP growths for one and two years ahead. However, aggregate non-operating income does not have such predictive power. The results also support the statement that earnings components provide incremental information content as well as prominent numbers to predict and expect future performance.

This study performs additional analysis to compare the predictive power of aggregate corporate earnings and their components in developed and developing countries as well as in the high and low earnings quality contexts. The results indicate a significant difference between developed and developing countries that aggregate non-operating income has predictive power. The research findings also denote substantial differences between the high and the low earnings qualities that aggregate operating cash flows and accruals have their predictive power.

This study results in an implication that accounting numbers give practical support to forecasting the macroeconomic indicators. The research findings imply that economists and accountants could use accounting numbers as leading predictors to forecast macroeconomic indicators, especially the future GDP growths. In other words, these findings strengthen the substantial role that microdata is beneficial for predicting macroeconomics indicators.

This study has two main limitations. The first limitation comes from the research data which are mainly accounting numbers downloaded from the OSIRIS database. This limitation 
includes the availability of only restricted templates used to classify financial accounting data. Variable calculations highly depend on the availability of the structured templates in the OSIRIS database. The second limitation is associated with the proxy of earnings quality. This study employs earnings persistence as a proxy of earnings quality. However, this study noted that P. Dechow et al. (2010) suggested several proxies such as accrual magnitudes, residuals of the accrual model, and timely loss recognition. This research does not conduct sensitivity and robustness tests to investigate the effect of the different proxies themselves. Future research should consider the impact of these different proxies of the earnings quality measurements. Future studies can also examine the predictive power of accounting numbers on macroeconomic indicators other than the future GDP growths. Finally, future research can investigate the influence of country-specific factors other than those that have been considered in this study. There are many possibilities like countries' degree of corruption and financial inclusion.

\section{Acknowledgement}

We are grateful to the Master and Doctoral Program, Faculty of Economics and Business, University of Gadjah Mada (UGM). The Public and Social Fund Item, Faculty of Economics and Business, University of Gadjah Mada supported and financed all research activities up to its reporting.

\section{References}

Anilowski, C., Feng, M., \& Skinner, D. J. (2007). Does Earnings Guidance Affect Market Returns? The Nature and Information Content of Aggregate Earnings Guidance. Journal of Accounting and Economics, 44(1-2), 36-63. doi:10.1016/j.jacceco.2006.09.002

Ball, R., Sadka, G., \& Sadka, R. (2009). Aggregate Earnings and Asset Prices. Journal of Accounting Research, 47(5), 1097-1133.

Ball, R., \& Shivakumar, L. (2005). Earnings Quality in UK Private Firms: Comparative Loss Recognition Timeliness. Journal of Accounting and Economics, 39(1), 83-128. doi:10.1016/j.jacceco.2004.04.001

Barth, M. E., Beaver, W. H., Hand, J. R., \& Landsman, W. R. (1999). Accruals, Cash Flows, and Equity Values. Review of Accounting Studies, 4(3-4), 205-229.

Barth, M. E., Beaver, W. H., \& Wolfson, M. A. (1990). Components of Earnings and the Structure of Bank Share Prices. Financial Analysts Journal, 46(3), 53-60.

Barth, M. E., Cram, D. P., \& Nelson, K. K. (2001). Accruals and the Prediction of Future Cash Flows. The Accounting Review, 76(1), 27-58.

Bowen, R. M. (1981). 1979 Competitive Manuscript Award: Valuation of Earnings Components in the Electric Utility Industry. Accounting Review, 1-22.

Bratten, B. M. (2009). Analysts' Use of Earnings Components in Predicting Future Earnings. Dissertation., The University of Texas at Austin.

Dechow, P., Ge, W., \& Schrand, C. (2010). Understanding Earnings Quality: A Review of the Proxies, Their Determinants and Their Consequences. Journal of Accounting and Economics, 50(2-3), 344-401.

Dechow, P. M., \& Dichev, I. D. (2002). The Quality of Accruals and Earnings: The Role of Accrual Estimation Errors. The Accounting Review, 77(s-1), 35-59.

Fairfield, P. M., Sweeney, R. J., \& Yohn, T. L. (1996). Accounting Classification and the Predictive Content of Earnings. Accounting Review, 337-355.

Finger, C. A. (1994). The Ability of Earnings to Predict Future Earnings and Cash Flow. 
Journal of Accounting Research, 210-223.

Foster, L., Haltiwanger, J., \& Krizan, C. J. (2006). Market selection, reallocation, and restructuring in the US retail trade sector in the 1990s. The Review of Economics and Statistics, 88(4), 748-758.

Foster, L., Haltiwanger, J. C., \& Krizan, C. J. (2001). Aggregate productivity growth: Lessons from microeconomic evidence New developments in productivity analysis (pp. 303-372): University of Chicago Press.

Gonedes, N. J. (1973). Properties of Accounting Numbers: Models and Tests. Journal of Accounting Research, 212-237.

Gonedes, N. J. (1975). Risk, Information, and the Effects of Special Accounting Items on Capital Market Equilibrium. Journal of Accounting Research, 220-256.

Griffin, P. A. (1977). The Time-series Behavior of Quarterly Earnings: Preliminary Evidence. Journal of Accounting Research, 71-83.

Harvey, C. R. (1989). Forecasts of Economic Growth from the Bond and Stock Markets. Financial Analysts Journal, 45(5), 38-45.

Konchitchki, Y., \& Patatoukas, P. N. (2014a). Accounting Earnings and Gross Domestic Product. Journal of Accounting and Economics, 57(1), 76-88.

Konchitchki, Y., \& Patatoukas, P. N. (2014b). Taking the Pulse of the Real Economy Using Financial Statement Analysis: Implications for Macro Forecasting and Stock Valuation. The Accounting Review, 89(2), 669-694. doi:10.2308/accr-50632

Kothari, S., Lewellen, J., \& Warner, J. B. (2006). Stock Returns, Aggregate Earnings Surprises, and Behavioral Finance. Journal of Financial Economics, 79(3), 537-568.

Kothari, S., Shivakumar, L., \& Urcan, O. (2013). Aggregate Earnings Surprises and Inflation Forecasts. Unpublished Paper, MIT Sloan School of Management and London Business School.

Lilien, D. M. (1982). Sectoral shifts and cyclical unemployment. Journal of political economy, 90(4), 777-793.

Lipe, R. C. (1986). The Information Contained in the Components of Earnings. Journal of Accounting Research, 24, 37-64. doi:10.2307/2490728

Lucas, R. E., \& Prescott, E. C. (1974). Equilibrium search and unemployment. Journal of Economic theory, 7(2), 188-209.

McCloskey, D. N. (1993). Schelling's Five Truths of Economics. Eastern Economic Journal, 19(1), 109-111.

Patatoukas, P. N. (2014). Detecting News in Aggregate Accounting Earnings: Implications for Stock Market Valuation. Review of Accounting Studies, 19(1), 134-160.

Richardson, S. A., Sloan, R. G., Soliman, M. T., \& Tuna, I. (2005). Accrual Reliability, Earnings Persistence and Stock Prices. Journal of Accounting and Economics, 39(3), 437485.

Schneider, F. (2005). Shadow Economies Around the World: What Do We Really Know? European Journal of Political Economy, 21(3), 598-642.

Schumpeter, J. A. (2003). Capitalism, Socialism and Democracy: Taylor \& Francis e-Library.

Shivakumar, L. (2007). Aggregate Earnings, Stock Market Returns and Macroeconomic Activity: A Discussion of 'Does Earnings Guidance Affect Market Returns? The Nature and Information Content of Aggregate Earnings Guidance'. Journal of Accounting and Economics, 44(1-2), 64-73. doi:10.1016/j.jacceco.2006.12.001

Sloan, R. G. (1996). Do Stock Prices Fully Reflect Information in Accruals and Cash Flows about Future Earnings? Accounting Review, 289-315.

Wang, H., Cao, F., Li, S., \& Liu, X. (2015). Can Accounting Earnings Predict Future GDP Growth? Evidence from China. Frontiers of Business Research in China, 9(1), 30-43. 